\title{
SOSIALISASI DAN PENDAMPINGAN DIGITAL MARKETING DI ERA PANDEMI COVID 19 PADA KELOMPOK WANITA TANI KELURAHAN TEMBONG KOTA SERANG
}

\author{
Endang Tri Santi*, Marthalena, Eva Fachriyah \\ Prodi Ilmu Komunikasi Fisipkum Universitas Serang Raya \\ Corresponding author*: endangts@unsera.ac.id
}

\begin{abstract}
Covid 19 has an impact on the economic decline evenly, one of which is the level of people's purchasing power decreases. Coupled with the existence of social restrictions that do not allow people to interact with each other, it greatly affects sales revenue, especially marketing that still uses and relies on conventional systems. Therefore, there is a need for assistance to do digital marketing, especially in this era of sophisticated technology. Because it is undeniable that online marketing is an alternative, not just to keep up with the times, but also a way to adapt to the pandemic conditions that have not subsided. The purpose of this activity is to conduct socialization and assistance to the community, especially women farmer groups regarding how to make product packaging techniques attractive and marketing techniques through digital, with the hope that people will not only do conventional marketing but also digitally. The method used is by socializing or delivering digital marketing materials and theories, as well as direct practical assistance on how to package products, take product photos, use social media, and so on. From the assistance that has been carried out by women farmer groups, they can apply social media including whatsapp and facebook as a means of making sales so that the products or agricultural products they market more attract the wider community.
\end{abstract}

Keywords: Digital Marketing, Covid 19, Social Media

\begin{abstract}
Abstrak
Covid 19 memberikan dampak penurunan ekonomi secara merata, salah satunya tingkat daya beli masyarakat menurun. Ditambah dengan adanya pembatasan sosial yang tidak memperkenankan masyarakat untuk saling berinteraksi, sangat mempengaruhi pendapatan hasil penjualan, terutama pemasaran yang masih menggunakan dan mengandalkan sistem konvensional. Oleh karenanya perlu adanya pendampingan untuk melakukan pemasaran secara digital, terlebih di era teknologi yang serba canggih ini. Karena tidak dapat dipungkiri bahwa, pemasaran melalui online menjadi salah satu alternatif, bukan hanya untuk mengikuti zaman semata, tetapi salah satu cara beradaptasi terhadap kondisi pandemi yang belum mereda. Tujuan kegiatan ini adalah melakukan sosialisasi dan pendampingan kepada masyarakat terutama kelompok wanita tani mengenai bagaimana teknik packaging produk supaya menarik dan teknik pemasaran melalui digital, dengan harapan masyarakat tidak hanya melakukan pemasaran secara konvensional tetapi juga digital. Metode yang digunakan adalah dengan sosialisasi atau penyampaian materi dan teori pemasaran digital, serta pendampingan praktik langsung tentang bagaimana packaging produk, photo produk, menggunakan media sosial, dan lain sebagainya. Dari pendampingan yang telah dilakukan kelompok wanita tani dapat mengaplikasikan media sosial diantaranya whatsapp dan facebook sebagai sarana melakukan penjualan agar produk atau hasil tani yang mereka pasarkan lebih menjaring masyarakat luas.
\end{abstract}

Kata kunci : Pemasaran Digital, Covid 19, Media Sosial

Copyright $($ 2021, Endang Tri Santi, Marthalena, Eva Fachriyah This is an open access article under the CC-BY NC-SA license. http:// DOI 10.30656/ps2pm.v3i2.4049

Endang Tri Santi, Marthalena, Eva Fachriyah. Sosialisasi dan Pendampingan Digital Marketing di Era Pandemi Covid-19 pada Kelompok Wanita Tani Kelurahan Tembong Kota Serang 


\section{PENDAHULUAN}

Pandemi Covid 19 memberikan dampak secara merata pada penurunan pertumbuhan ekonomi bangsa Indonesia. Sebetulnya tidak hanya di Indonesia, bahkan lahirnya covid 19 telah merubah perekonomian dunia (Sarip, 2020). Dampaknya dirasakan baik dari area perkotaan sampai ke perdesaan, begitu pun yang dirasakan oleh kelompok wanita tani yang ada di kelurahan Tembong Kota Serang. Apabila di amati, dampak pandemi bisa menjadi sebuah ancaman namun juga dapat menjadi sebuah peluang tersendiri bagi para pengelola hasil tani untuk memasarkan produknya sehingga dapat laku di pasaran. Kelompok wanita tani merupakan salah satu komunitas yang ada di Kelurahan Tembong yang menghimpun para wanita dengan fokus mengembangkan produk pertanian.

Sumber daya dan hasil tani yang ada di Kelurahan Tembong ini sangat beragam, mulai dari sayur mayur, umbi-umbian, kacangkacangan, hingga lain sebagainya. Namun yang belum dipahami adalah kurangnya strategi pemasaran yang dapat dilakukan oleh kelompok wanita Tani di Tembong. Selain sayur mayur, salah satu produk yang dihasilkan adalah Gipang yakni makanan ringan yang menjadi makanan khas Banten serta terbuat dari beras ketan olahan dengan kacang tanah. Produk Gipang yang dihasilkan dari Kelurahan Tembong ini sebenarnya sudah banyak dikenal di pasaran, hanya saja baru sampai di area pasar Serang.

Sementara untuk hasil tani nya sendiri, Kelompok Wanita Tani kelurahan Tembong mengatakan bahwa hasil tani mereka yang sudah dipasarkan adalah wortel, kangkung, kacang panjang, bayam dan lain-lain, namun seperti halnya pemasaran makanan ringan bipang, sayur mayur ini pun dijual masih dengan cara konvensional di pasar bahkan masih dari mulut-ke mulut atau ke tetangga 
masing-masing, meskipun menurut salah satu wanita tani mengatakan bahwa hasil tani mereka sangat dapat bersaing di pasaran karena sayur mayurnya hasil panen mereka lebih segar dan berbibit baik dan tidak kalah saing dibanding yang ada di supermarket.

Dampak pandemi covid 19 seperti yang telah disinggung di atas, sedikit banyak mempengaruhi pemasaran hasil tani kelompok wanita tani Tembong meskipun tidak terlalu signifikan mengalami penurunan penjualan, tetapi dari hasil observasi yang ada, sebetulnya terdapat peluang di masa pandemi ini bagaimana kelompok wanita tani ini dapat memasarkan hasil tani mereka secara online atau digital. Karena seperti yang kita ketahui bahwa saat ini sudah memasuki era digital 4.0 di mana setiap kita harus mampu dan mau beradaptasi dengan kemajuan teknologi (Riyadus Solihin, 2019). Salah satunya dalam menjalankan pemasaran dengan menggunakan kecanggihan teknologi.

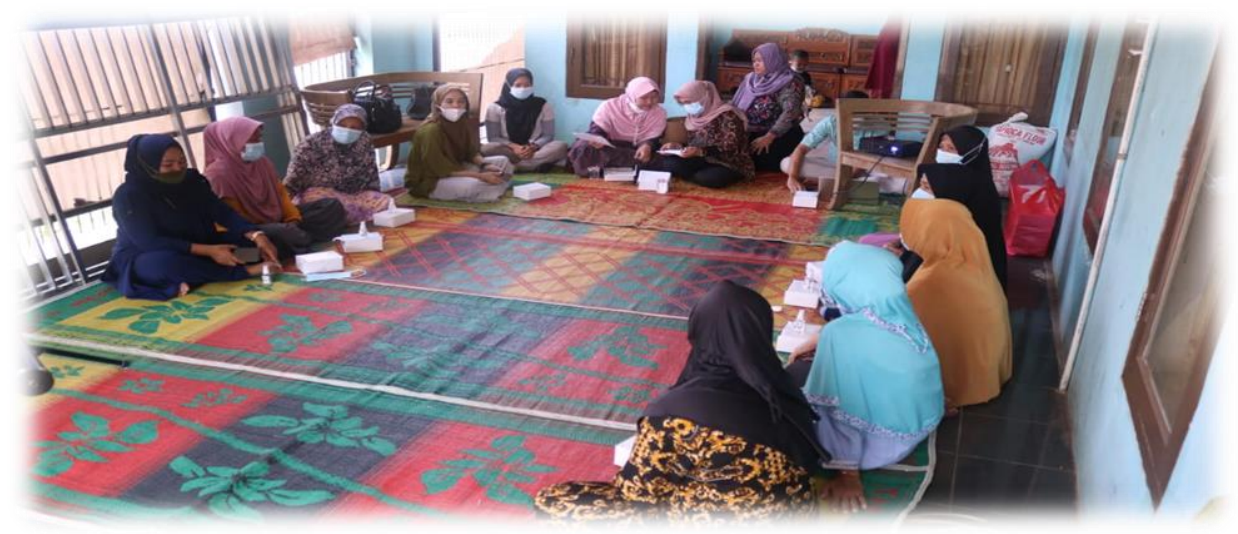

Gambar 1.

Proses diskusi bersama Kelompok wanita Tani Kelurahan Tembong Kota Serang

Berdasarkan hasil diskusi mereka bukan hanya bisa diterima bersama kelompok wanita tani hal oleh masyarakat sekitar, tetapi juga yang mereka butuhkan salah satunya dapat diterima masyarakat secara bagaimana cara memasarkan produk luas. Hal ini tentu perlu adanya 
strategi pemasaran yang tepat, sebagaimana yang dikatakan oleh Nugrahani bahwa strategi pemasaran merupakan komponen esensial yang mampu mengendalikan keberhasilan penjualan produk di masyarakat luas meskipun banyak sekali yang menganggap belum terlalu penting (Syaeful Bakhri, 2020).

Fenomena yang telah dijelaskan di atas memberikan temuan bahwa sangat perlu adanya pendampingan pemasaran digital yang dapat dilakukan untuk para kelompok wanita tani. Adapun pemasaran secara digital yang akan dilakukan dapat disesuaikan dengan fasilitas serta kemampuan penggunanya untuk berinteraksi atau menukar informasi melalui platform yang telah tersedia di dunia digital saat ini. Salah satu contohnya dengan menggunakan Whatssap, Facebook, Instragram, dan lain-lain. Mengingat kelompok wanita tani kelurahan Tembok beranggotakan ibu-ibu muda dan paruh baya dengan target marketnya pun ibu-ibu, maka platform media digital yang cocok digunakan dalam pemasaran sayur mayur hasil tani mereka adalah dengan menggunakan whatsapp dan facebook.

Dari pokok permasalahan dan pemaparan tersebut di atas, dan dalam rangka pengabdian kepada masyarakat maka diakukan pelatihan digital marketing di era pandemi covid 19 pada kelompok wanita tani Kelurahan Tembong Kota Serang, dengan harapan agar dapat memperluas jangkauan pasar sehingga target market terlaksana dengan baik dan dapat mempengaruhi peningkatan dalam penjualan hasil usaha tani di kelurahan Tembong Kota Serang.

\section{METODE PELAKSANAAN}

Adapun metode yang digunakan dalam melaksanakan kegiatan pengabdian masyarakat ini adalah dengan cara melakukan sosialisasi dan pendampingan mengenai pemasaran digital di masa 
pandemic covid 19. Namun sebelum melakukan sosialisasi

dan pendampingan pada kelompok wanita tani, sebelumnya dilakukan teknik pengumpulan data yakni dengan melakukan observasi, wawancara dan dokumentasi. Metode pengumpulan data yang dilakukan dalam pengabdian ini adalah dengan menggunakan data primer dan data sekunder. Data primer yang dilakukan adalah dengan melakukan observasi langsung terhadap kelompok wanita tani dengan mewawancarai secara mendalam mengenai bagaimana cara pengemasan dan pemasaran yang bisa dilakukan untuk menaikan penjualan hasil tani.

Selain data primer, sumber data yang digunakan adalah sumber data sekunder, yakni data yang berdasarkan bacaan dari buku, hasil penelitian, dan kepustakaan yang menjadi data penunjang. Data sekunder ini digunakan untuk dokumen penunjang dalam pelatihan ini agar mampu merumuskan strategi apa saja yang harus dilakukan dalam pengabdian masyarakat di kelompok wanita tani kelurahan Tembong.

Setelah memperhatikan data primer dan sekunder, maka metode yang digunakan dalam pengabdian masyarakat ini berupa kegiatan sosialisasi dan pendampingan mulai dari bagaimana cara melakukan pengemasan (packaging) sampai dengan cara penjualan menggunakan media whatsapp dan facebook. Kegiatan pelatihan ini menggunakan media komunikasi yang mudah dipahami oleh kelompok wanita tani. Adapun pendampingan ini berupa sosialisasi mengenai cara pengemasan sayur mayur yang menarik dipasaran sehingga dapat mempengaruhi penjualan.

Setelah dilakukan pelatihan cara packaging kemudian diadakan sosialisasi dan pendampingan cara mengambil gambar/memfotho sampai dengan mengedit photo produk sehingga menjadi produk 
yang menarik minat pembeli. Setelah menghasilkan photo produk yang menarik lalu kelompok wanita tani tersebut diberikan pendampingan mengenai cara mengupload sesuai dengan jam-jam strategis di mana pengguna media sosial sedang ramai, misalnya jika upload di Facebook dapat dilakukan di jam 13.00 sampai dengan pukul 14.00, di mana biasanya para pekerja atau ibu-ibu sedang beristirahat dari rutinitas sehingga mengisi waktu luang dengan membuka media sosial.

Pendampingan yang diberikan kepada kelompok wanita tani tidak hanya teori saja, melainkan praktik langsung yang dilakukan oleh ibu-ibu wanita tani kelurahan Tembong dengan harapan setelah mendapat pelatihan tersebut, ibu-ibu kelompok wanita tani lebih bersemangat untuk melakukan pemasaran secara online. Hal ini di rasa sangat efektif untuk meningkatkan pemasaran/penjualan sayur-mayur hasil tani yang selama ini dijual dalam bentuk pasar yang konvensional bahkan hanya dari mulut ke mulut. Dengan harapan pendampingan ini ikut membuka peluang kemajuan pasar bagi kelompok wanita tani. Jumlah peserta yang mengikuti pendampingan ini kurang lebih 20 orang peserta yang semuanya adalah anggota Kelompok Wanita Tani Kelurahan Tembong Kota Serang.

\section{HASIL DAN PEMBAHASAN}

Covid 19 menjadi momok yang tidak pernah diprediksi oleh masyarakat sebelumnya karena merupakan pandemi global, di mana sangat mempengaruhi laju perekonomian yang menurun dan hampir merata dirasakan oleh seluruh lapisan masyarakat, pemenuhan kebutuhan yang harus dipenuhi masyarakat menjadi konsen bersama yang harus secara cermat ada solusi yang harus dilakukan. Salah satu langkah strategis yang harus dilakukan adalah beradaptasi dengan kondisi pandemic covid 19, 
sebagaimana telah dikatakan di awal bahwa kondisi ini dapat menjadi kelemahan, tantangan, tetapi juga dapat menjadi sebuah peluang apabila masing-masing kita memiliki daya kreativitas yang tinggi dan mau mengaktualisasikan ide-ide segar yang ada.

Oleh karenanya tim pengabdian masyarakat merasa perlu adanya pendampingan yang diadakan untuk kelompok wanita tani kelurahan Tembong, selain untuk menambah wawasan dan juga pengetahuan, tetapi juga dapat dijadikan langkah untuk melakukan pemasaran online yang tentunya berguna untuk menambah dan meningkatkan penjualan hasil usaha tani yang menjadi produk utama kelompok wanita tani.

\section{Peserta}

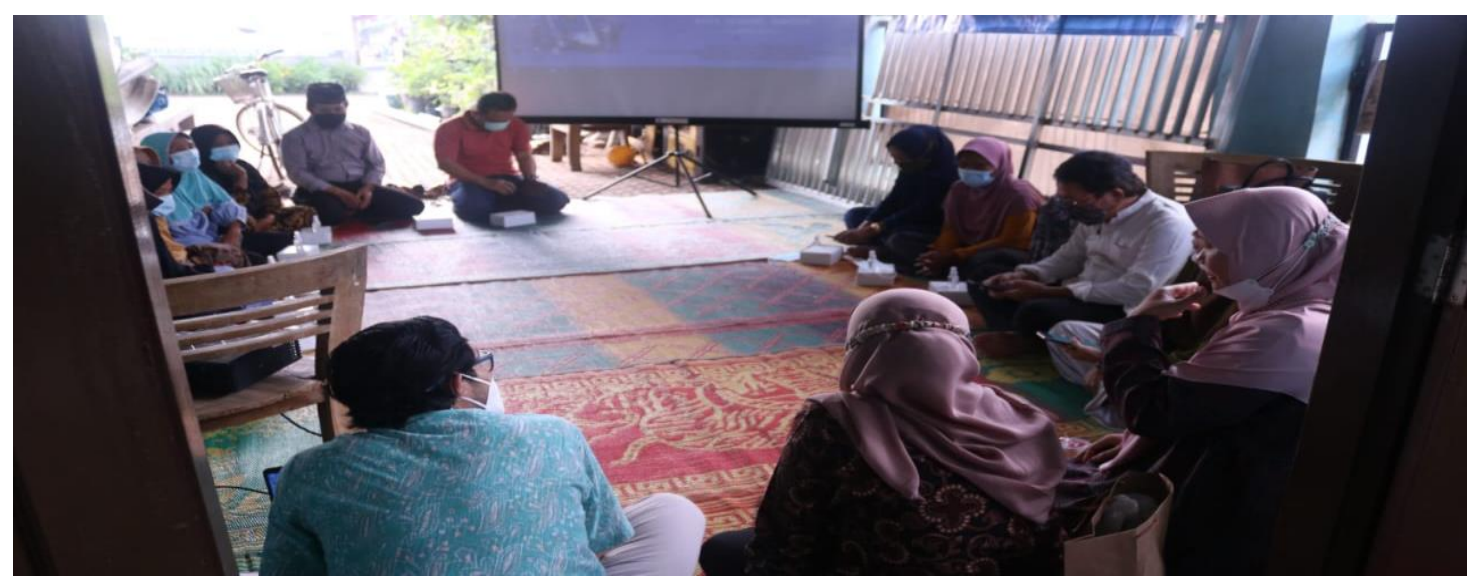

Gambar 2.

Proses Pembukaan sebelum memulai Pendampingan dan praktik digital marketing

Kegiatan sosialisasi dan kerap digunakan oleh kelompok pelatihan ini dilaksanakan di rumah wanita tani ketika ada agenda salah satu warga yang menjadi anggota kelompok wanita tani, selain letaknya strategis, tempat ini memang tertentu. Adapun peserta yang hadir dalam pelatihan ini merupakan anggota kelompok tani yang ada di

Endang Tri Santi, Marthalena, Eva Fachriyah. Sosialisasi dan Pendampingan Digital Marketing di Era Pandemi Covid-19 pada Kelompok Wanita Tani Kelurahan Tembong Kota Serang 
kelurahan Tembong, di mana pesertanya adalah sebagian besar perempuan. Peserta yang hadir dalam pendampinga tersebut kurang lebih 20 orang peserta dan semuanya adalah perempuan.

Di tengah kondisi covid 19 ini, pelaksanaan sosialisasi dan pendampingan ini sangat menjaga protokol kesehatan yang sangat ketat dan sesuai dengan anjuran pemerintah. Tentunya hal ini patut menjadi komitmen bersama ketika mengadakan pertemuan, terutama yang sifatnya rembug dan bersamasama dalam satu tempat untuk waktu yang cukup lama.

2. Pelaksanaan Kegiatan Pengabdian Masyarakat

Kegiatan pengabdian dilakukan di Kelurahan Tembong yang dilaksanakan pada 09 April 2021. Adapun tahapan yang dilakukan selama sosialisasi dan pendampingan terhadap kelompok wanita tani kelurahan tembong terbagi atas 3 tahapan, yakni : a) Tahap awal pendampingan

- Pada tahapan ini dilakukan observasi dan survey lapangan untuk mengetahui informasi secara mendalam permasalahan yang ada pada kelompok wanita tani kelurahan Tembong guna mencari rencana strategis dan solusi yang tepat sasaran dan dibutuhkan.

- Melengkapi prosedur administrasi sebagai bukti bahwa kegiatan pengabdian ini sifatnya resmi

- Merancang rencana dan menyusun agenda kegiatan yang akan dilakukan sebagai upaya untuk membantu dan mengembangkan daya jual produk peserta pendampingan peserta

b) Tahap Inti Pendampingan Pada tahap inti ini lebih fokus kepada kegiatan apa yang dilakukan pada saat sosialisasi dan pendampingan, diantaranya ; 


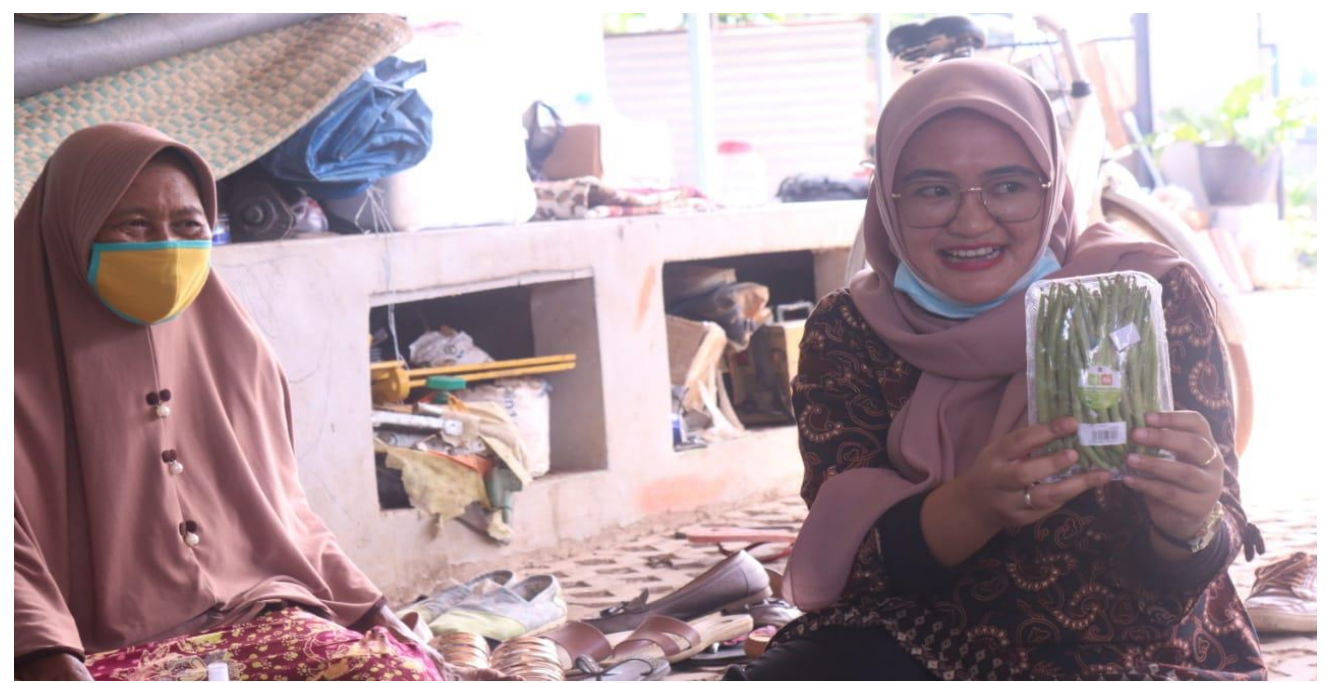

Gambar 3.

Proses pendampingan praktik Cara packaging yang menarik untuk sayur mayur

\begin{tabular}{|c|c|c|}
\hline No & Nama Kegiatan & Keterangan \\
\hline 1. & $\begin{array}{l}\text { Praktik Pengemasan Produk } \\
\text { (Packaging Produk) }\end{array}$ & $\begin{array}{l}\text { Pada materi ini peserta diberikan } \\
\text { pengarahan dan diajarkan bagaimana } \\
\text { cara mengklasifikasi sayur-mayur yang } \\
\text { layak, bersih, dan segar, lalu dijadikan } \\
\text { dalam packaging yang menarik, rapih } \\
\text { dan tentunya menarik minat pembeli }\end{array}$ \\
\hline & Praktik Pengambilan Fhoto & $\begin{array}{l}\text { Pada materi ini peserta diajarkan untuk } \\
\text { praktik secara langsung bagaimana } \\
\text { memanfaatkan kamera telepon } \\
\text { genggam untuk mengambil gambar } \\
\text { atau fhoto yang menarik, lalu diajarkan } \\
\text { untuk mengedit gambar tersebut } \\
\text { sehingga calon user atau pembeli } \\
\text { tertarik untuk menggunakan atau } \\
\text { membeli produk yang dipasarkan. }\end{array}$ \\
\hline
\end{tabular}

3. Membuatan berbagai akun Pada materi ini peserta pendampingan media sosial (Whatsapp, diajarkan cara membuat akun facebook, dan Instagram) diberbagai media sosial, terutama facebook dan whatsapp yang paling sering digunakan oleh para ibu-ibu. Selain itu banyak pula akun jual beli

Endang Tri Santi, Marthalena, Eva Fachriyah. Sosialisasi dan Pendampingan Digital Marketing di Era Pandemi Covid-19 pada Kelompok Wanita Tani Kelurahan Tembong Kota Serang 
4. Praktik Copywriting dan Konten

yang terdapat di platform ini merupakan salah satu wadah berjualan yang cukup memiliki pengaruh.

Materi ini memberikan pelatihan bagaimana peserta dapat membuat caption di media sosial dengan konten yang sesuai dengan product yang akan dipasarkan.

5. Praktik upload / publikasi Setelah proses praktik pengambilan konten dari produk yang gambar, pembuatan akun, pembuatan dimiliki caption dan konten, tahapan pelatihan berikutnya adalah bagaiman cara menshare produk sesuai dengan timing atau jam penting untuk promosi.

6. Praktik Komunikasi dan cara Proses ini merupakan praktik yang membalas pesan masuk penting di mana dalam psikologis dengan calon user pembeli akan merasa senang dan nyaman ketika komunikasi dengan pedagang lancar dan nyaman. Sehingga peserta diajarkan bagaimana cara menawarkan produk salah satunya dengan cara merespon pertanyaan calon pelanggan. Lalu diajarkan pula cara memantainance pembeli agar kembali mengunjungi dan membeli produk yang kita jual.

3. Evaluasi Kegiatan Pengabdian Masyarakat

Pada tahapan ini adalah tahapan pengukuran dan evaluasi apakah kegiatan pengabdian masyarakat ini dapat berjalan dengan baik atau tidak, Gunanya adalah untuk mengetahui kekurangan dan kelebihan kegiatan pengabdian masyarakat ini secara menyeluruh, sehingga dapat menjadi bahan perbaikan di kemudian. Evaluasi kegiatan ini juga dapat dijadikan bahan acuan untuk mengembangkan metode pendampingan seperti apa yang cocok dilakukan pada era saat ini. Dari hasil evaluasi kegiatan ini, hendaknya pendampingan dilakukan 
secara terus - menerus dan benarbenar mendampingi kelompok wanita tani dari hulu ke hilirnya.

\section{SIMPULAN}

Kegiatan sosialisasi dan pendampingan ini merupakan langkah untuk berkontribusi di tengah masyarakat dengan harapan informasi dan praktik yang dilakukan dapat membawa manfaat dan faedah tersendiri khususnya bagi kelompok wanita tani, dan umumnya kontribusi terhadap kemajuan bangsa Indonesia. Kegiatan ini dirasa cukup efektif dan efisien di tengah kondisi saat ini, banyaknya masukan mengenai agar kegiatan seperti ini diperbanyak dan berkelanjutan merupakan tambahan semangat tersendiri bagi tim pengabdian masyarakat. Harapan berikutnya semoga pendampingan praktik pemasaran secara digital yang telah diajarkan dapat membawa manfaat dan membawa energi positif untuk terus maju. Dengan adanya kegiatan ini semoga menjadi stimuli tersendiri bagi masyarakat untuk memanfaatkan peluang yang ada. Selanjutnya, selain melakukan pemasaran secara digital, hendaknya dikemudian hari diadakan pelatihan pembukuan atau keuangan bagi anggota Kelompok Wanita Tani.

\section{UCAPAN TERIMA KASIH}

Ucapan terima kasih yang tak terhingga kami sampaikan kepada pihak yang telah banyak membantu dan bekerjasama melancarkan kegiatan ini, kepada prodi Ilmu Komunikasi Unsera dan Kelohjk \lmpok Wanita Tani Kelurahan Tembong kota Serang yang telah sama-sama memberikan energi positif untuk terus berkarya dan belajar bersama.

\section{REFERENSI}

Riadhus Sholihin. 2019. Digital Marketing di Era 4.0. Yogyakarta : Quadran

Andi Yusika Rangan, Dkk. Pendampingan Pemanfaatan Media Sosial Sebagai Sarana Membangun Citra Pondok

Endang Tri Santi, Marthalena, Eva Fachriyah. Sosialisasi dan Pendampingan Digital Marketing di Era Pandemi Covid-19 pada Kelompok Wanita Tani Kelurahan Tembong Kota Serang 
Pesantren Nurul Mustafa AlHusaini. Vol.3 No.1 Hal.1-9

https://e-

jurnal.lppmunsera.org/index. php/PS2PM/

article/view/3344 (diakses

pada 23 November 2021)

Hawangga Dhiyaul Fadly \& Sutama.

2020. Membangun Pemasaran

Online dan Digital Branding

Di Tengah Pandemi Covid 19.

Vol.5 No 2. 213-222.

http://ejournal.uigm.ac.id/ind

ex.php/EG/article/view/1042/

1115 (diakses pada 22

November 2021)

Sarip, Dkk. Dampak Covid 19

Terhadap Perekonomian

Masyarakat dan

Pembangunan Desa. 2020.

Vol.5 No 1. Hal. 10-20.

https://www.researchgate.net

Lprofile/Abdul-Muaz-

2/publication/344023323

(diakses pada 23 November

2021)

Syaful Bahri \& Vuvut Futiah. 2020.

Pendampingan dan

Pengembangan Manajemen

Pemasaran Produk UMKM

Melalui Tenologi Digital di

Masa Pandemi Covid-19.

Vol.2 no 2, h.59-70.

https://scholar.google.com/sc

holar?hl=id\&as $\mathrm{sdt}=0 \% 2 \mathrm{C5} \&$

$q=\quad$ (diakses pada 22

November 2021) 